\title{
EVALUASI PENATAAN KAWASAN PERMUKIMAN KUMUH (STUDI KASUS: PROGRAM PEREMAJAAN KAWASAN TEGALPANGGUNG DI KOTA YOGYAKARTA)
}

\author{
Bani Putri Yulianti' ${ }^{1}$, M. Baiquni ${ }^{2}$, Su Ritohardoyo ${ }^{3}$, Hadi Sabari Yunus ${ }^{4}$ dan Bakti Setiawan ${ }^{5}$
}

Fakultas Geografi Universitas Gadjah Mada, Yogyakarta, Indonesia ${ }^{1,2,3,4,5}$

banipyo@gmail.com

Diterima : Juni 2014; Direvisi: Agustus 2014.; Dipubikasikan: 31 Maret 2015

\begin{abstract}
ABSTRAK Peningkatan jumlah penduduk pada wilayah Kota Yogyakarta menimbulkan semakin banyak permasalahan permukiman yang ditimbulkan. Permukiman kumuh merupakan salah satu permasalahan permukiman yang ada di Kelurahan Tegalpanggung Kota Yogyakarta. Sebagai upaya untuk mengatasi permasalahan tersebut maka pemerintah Kota Yogyakarta menata dan meremajakan kembali prasarana lingkungan kawasan yang berada di bantaran sungai Code termasuk di permukiman kumuh Tegalpanggung yang sudah terbentuk secara organis dalam waktu yang lama. Tujuan dari penelitian ini adalah menganalisa kondisi lingkungan sebelum dan pasca penataan kawasan di daerah Tegalpanggung dan menganalisa keberhasilan terhadap program penataan kawasan Tegalpanggung menurut persepsi masyarakat setempat. Pengumpulan data penelitian menggunakan metode survey dengan menggunakan daftar pertanyaan (kuesioner) kepada 40 responden. Penentuan sampel digunakan metode penelitian sampling (sampling method), dengan jenis teknik sampling yang digunakan adalah pengambilan sampel secara acak (random sampling). Dalam melakukan analisis terhadap dampak relokasi digunakan metode before after comparation, untuk mengetahui perubahan yang terjadi. Hasil data selanjutnya dilakukan pengolahan secara metode analisis deskriptif kualitatif dan kuantitatif. Dengan analisis tersebut maka dapat diketahui tingkat signifikasi perubahan yang terjadi setelah program peremajaan yang dilakukan di Kelurahan Tegalpanggung. Hasil penelitian menunjukkan Kepuasan masyarakat terhadap pelaksanaan program Penataan dan Peremajaan Prasarana Lingkungan Permukiman Tegalpanggung adalah sebesar 56\% yang berarti masyarakat menyatakan cukup puas terhadap program ini berarti menunjukkan bahwa program penataan dan peremajaan prasarana lingkungan cukup berhasil dalam memberikan nilai kepuasan terhadap masyarakat. Dari aspek sarana dan prasarana (menurut kriteria kawasan kumuh oleh Departemen PU, 2007) dapat disimpulkan sebagian besar kondisi prasarana lingkungan yang ada termasuk dalam kategori kumuh sedang.
\end{abstract}

Kata kunci: evaluasi; keberhasilan; peremajaan; permukiman kumuh; prasarana; Tegalpanggung.

ABSTRACT Increasing the number of residents in the city of Yogyakarta, causing more and more problems posed settlements. Slum is one of the problems in existing settlements in the Village Tegalpanggung Yogyakarta. In an effort to overcome these problems, the government of Yogyakarta organize and rejuvenate the environmental infrastructure are areas along the river Code including in slums Tegalpanggung already formed organically in a long time. The aim of this study was to analyze the environmental conditions before and after the arrangement of the region in the area Tegalpanggung and analyze the success of the restructuring program Tegalpanggung region as perceived by local people. Data collection research using survey method using a questionnaire (questionnaire) to 40 respondents. The samples used research methods of sampling (sampling method), the type of sampling technique used is random sampling (random sampling). In an analysis of the impact of the relocation of the method used before after comparation, to determine the changes that occur. Results of further data processing is done by the method of qualitative and quantitative descriptive analysis. With this analysis it can be seen the level of significance of the changes that occur after rejuvenation program conducted in the Village Tegalpanggung. The results showed public satisfaction towards the implementation of the program Structuring and Environmental Infrastructure Upgrades Tegalpanggung Settlement is 56\%, which means people stated quite satisfied with this program means indicates that the Setup program and renewal of environmental infrastructure is quite successful in delivering value to the community satisfaction. From the aspect of infrastructure (according to the criteria of slum areas by the Department of Public Works, 2007) can be summed up most of the environmental conditions existing infrastructure included in the category of medium slum.

Keywords: evaluation; succes; revitalization; urban slum; Infrastructure; Tegalpanggung. 


\section{PENDAHULUAN}

Letak kawasan Tegalpanggung terhadap Kota Yogyakarta yang berada di tengah, merupakan potensi karena kedekatan dengan sumber ekonomi. Oleh karena itu, Kawasan Tegalpanggung menjadi incaran para pendatang (urbanis) untuk bermukim, sehingga lingkungan perumahan semakin padat. Kepadatan bangunan bisa dikategorikan sangat tinggi (lebih dari $80 \%)$ dan ruang terbuka hijau sulit ditemukan. Luas area Kawasan Tegalpanggung adalah 35,06 Ha, dengan jumlah penduduk pada tahun 2013 sebanyak 9.100 orang, terdiri dari penduduk laki-laki 4.511 orang dan 4.589 orang perempuan, (sumber data diambil dari data Kelurahan Tegal Panggung tahun 2013 dan survey lapangan tahun 2013).

Program penataan kawasan Tegalpanggung yang diwujudkan dengan adanya Rencana Teknik (DED) ini di rancang untuk menjawab permasalah permukiman terdahulu, yaitu : kondisi permukiman yang memiliki kepadatan tinggi, kumuh, dan penuh sampah sehingga rawan terhadap bahaya kebakaran, tetapi kemudian yang menjadi masalah saat ini, fakta di lapangan menunjukan kondisi permukiman masih terlihat kumuh, sehingga muncul pertanyaan mengapa terjadi ketidaksesuaian antara Rencana Teknik (DED) dan penerapannya di permukiman Tegalpanggung.

Salah satu sebab dari kondisi tersebut di atas ini adalah karena tidak adanya keterkaitan antara pengetahuan (knowledge) dan penerapan atau implementasi (action), artinya terdapat krisis pemahaman tentang masyarakat terhadap penerapan program atau kegiatan penataan. Kebutuhan yang essential (hal-hal yang perlu atau pokok) dari masyarakat miskin masih belum tersentuh. Sehingga kebijakan yang dibuat tidak mampu menterjemahkan kepentingan dan kebutuhan masyarakat.

Tujuan dari penelitian ini dimaksudkan untuk mengevaluasi program peremajaan dan penataan kawasan Tegalpanggung yang sudah berjalan selama tujuh tahun. Secara khusus penelitian ini bertujuan untuk : 1) menganalisa kondisi prasarana lingkungan (Sanitasi (MCK), Taman dan Open Space, Drainase dan SPAH, Rusunawa, Jalan Lingkungan) sebelum dan pasca penataan kawasan di daerah Tegalpanggung; 2) menganalisa keberhasilan program penataan kawasan Tegalpanggung menurut persepsi masyarakat setempat.

Permukiman merupakan objek kajian geografi yang selalu berkaitan dengan ruang dimana manusia sebagai objek pokoknya dipelajari melalui pendekatan geografi yang dapat diartikan sebagai bentukan artifisial maupun natural dengan segala kelengkapanya yang digunakan oleh manusia, baik individu maupun kelompok, untuk bertempat tinggal baik sementara maupun menetap dalam rangka menyelenggarakan kehidupanya (Yunus, 1987: 3).

Istilah permukiman (settlement), seringkali dikacaukan dengan istilah pemukiman. Namun kedua kata terjemahan dari settlement mempunyai kaitan yang sangat erat yang mengacu kepada pengertian tempat tinggal atau tempat kediaman manusia hanya saja sebenarnya dua istilah ini dapat dibedakan secara tegas. Permukiman adalah tempat untuk bertempat tinggal, sedangkan pemukiman adalah cara bermukim atau hal memukim atau tegasnya cara atau hal menempati suatu tempat tinggal (Yunus, 2008).

Perkembangan permukiman dalam geografi permukiman pada saat ini lebih dipusatkan pada artificial settlements. Dimana secara kontinum keberadaan permukiman dapat dibedakan menjadi permukiman perkotaan (urban settlements), permukiman peralihan antara desa dengan kota (rurban settlements), dan permukiman desa (rural settlements) (Yunus, 1987: 20).

Pemukiman sering disebut perumahan dan atau sebaliknya pemukiman berasal dari kata housing dalam bahasa Inggris yang artinya adalah perumahan dan kata human settlement yang artinya pemukiman. Perumahan memberikan kesan tentang rumah atau kumpulan rumah beserta prasarana dan sarana lingkungan. Perumahan menitik beratkan pada fisik atau benda mati, yaitu houses dan land settlement. Pemukiman memberikan kesan tentang pemukim atau kumpulan pemukim beserta sikap dan perilakunya di dalam lingkungan, sehingga pemukiman menitik beratkan pada sesuatu yang bukan bersifat fisik atau benda mati yaitu manusia (human). Dengan demikian perumahan dan pemukiman merupakan dua hal yang tidak dapat dipisahkan dan sangat erat hubungannya, pada hakikatnya saling melengkapi (Kurniasih, 2007).

Kumuh adalah kesan atau gambaran secara umum tentang sikap dan tingkah laku yang rendah dilihat dari standar hidup dan penghasilan kelas menengah. Dengan kata lain, kumuh dapat diartikan sebagai tanda atau cap yang diberikan golongan atas yang sudah mapan kepada golongan bawah yang belum mapan. Gambaran seperti itu diungkapkan oleh Herbert J. Gans dengan kalimat sebagai berikut:

"Obsolescence per se is not harmful and designation of an area as a slum for the reason alone is merely a reflection of middle clas standards and middle alass incomes."

Beberapa kriteria permukiman kumuh menurut Yudohusodo dalam Ridlo (2001: 22), yaitu :

(a) Bentuk hunian tidak berstruktur; 
(b) Bentuk hunian tidak berpola dengan letak rumah dan jalan-jalannya tidak beraturan;

(c) Tidak tersedianya fasilitas umum;

(d) Tidak tersedia fasilitas, sarana dan prasarana permukiman dengan baik, misalnya tidak ada got, sarana air bersih dan jalan yang buruk.

Berkembangnya permukiman kumuh di perkotaan, menuntut adanya upaya untuk dilakukannya peremajaan, sejalan dengan pesatnya perkembangan dan pembangunan kota, yang tidak saja memperbaiki kondisi fisik kota yang berarti meningkatkan kualitas lingkungan kota, akan tetapi hal ini sekaligus dapat meningkatkan taraf hidup masyarakat.

Peremajaan permukiman kumuh sebagai bagian dari peremajaan kota oleh Yudohusodo (1991), dinyatakan sebagai upaya pembangunan yang terencana untuk merubah atau memperbaharui suatu kawasan kota yang mutu lingkungannya rendah. Dan peningkatan mutu lingkungan dimaksudkan untuk memperbaiki tatanan sosial ekonomi di kawasan bersangkutan, dan tatanan sosial ekonomi yang baru diharapkan dapat lebih mampu menunjang pengembangan wilayah kota lainnya karena naiknya efektifitas, efisiensi dan produktivitas kawasan tersebut setelah diremajakan, jadi peremajaan kota bukan semata-mata ditujukan kepada perbaikan fisiknya saja tetapi yang utama adalah perbaikan tatanan sosial ekonomi. Peremajaan permukiman kumuh, khususnya yang berkaitan dengan kegiatan peremajaan kota tidak dapat dipisahkan dari usaha untuk memberikan pelayanan perumahan yang layak kepada masyarakat.

Dunn (2000) menyatakan bahwa secara umum istilah evaluasi dapat disamakan dengan penaksiran (appraisal), pemberian angka (rating) dan penilaian (assesment). Evaluasi memberi informasi yang valid dan dapat dipercaya mengenai kinerja kebijakan, memberi sumbangan pada klarifikasi dan kritik terhadap nilai-nilai yang mendasari pemilihan tujuan dan target, juga memberi sumbangan pada aplikasi metoda-metoda analisis kebijakan lainnya, termasuk perumusan masalah dan rekomendasi.

Keadaan kota dengan permukiman kumuhnya dan semakin pesatnya pertambahan jumlah penduduk dan keterbatasan lahan di kota, sehingga mempengaruhi kondisi sosial ekonomi dalam masyarakatnya. Kondisi ini tentunya sangatlah terkait dengan timbulnya kantung-kantung kemiskinan dilihat dalam bentuk permukiman yang terjadi biasanya berupa permukiman kumuh (slum area) dan cenderung meluas serta berkaitan dengan kegiatan yang telah dilaksankan oleh pemerintah melalui Departemen Permukiman dan Prasarana Wilayah Tahun 2007, yaitu pelaksanaan program penataan dan rehabilitasi kawasan kumuh di kawasan Tegalpanggung, karenanya perlu dikaji atau mengevaluasi terhadap programprogram pemerintah dalam peremajaan dan penataan permukiman kumuh tersebut.

Kajian ini diawali dengan mengidentifikasi tingkat keberhasilan program pemerintah dalam upaya peremajaan dan penataan permukiman kumuh di Kawasan Tegalpanggung. Dari hasil beberapa proyek yang telah dilaksanakan di dinas maupun instansi yang ada di pemerintahan Kota Yogyakarta dapat menjadi data sekunder dalam menganalisa sementara kondisi permukiman kumuh yang terdapat di Kawasan Tegalpanggung.

Ditinjau dari kondisi prasarana permukiman, masyarakat, pendidikan, ketenagakerjaan, sosial ekonomi dan keterlibatan masyarakat dalam program penanganan peremajaan dan penataan permukiman kumuh yang telah dilaksanakan selama ini akan menjadi input yang dominan dalam keseluruhan penerlitian ini.

Bertolak dari permasalahan dan tujuan yang ingin dicapai, maka penelitian ini termasuk dalam penelitian terapan, yaitu penelitian terhadap suatu masalah dengan tujuan untuk digunakan bagi keperluan tertentu (Nazir, 1988). Dalam penelitian ini akan mengkaji dan mengevaluasi pelaksanaan program peremajaan dan penataan kawasan yang dilaksanakan di Kelurahan Tegalpanggung Kota Yogyakarta, karena program peremajaan yang telah selesai dilaksanakan ini belum pernah dilakukan evaluasi secara komprehensif sehingga belum diketahui keberhasilan dari program tersebut. Kajian dan evaluasi ini akan bermanfaat dan dapat dipergunakan sebagi input dalam pelaksanaan program yang sama dimasa yang akan datang maupun sebagai bentuk alternatif penanganan permukiman kumuh di Kota Yogyakarta.

\section{METODE PENELITIAN}

Pada penelitian ini lebih spesifik menggunakan metode penelitian sampling (sampling method). Hal ini dikarenakan metode tersebut dapat meminimalisir biaya, alokasi tenaga, dan waktu serta mampu memberikan gambaran yang nyaris sempurna terhadap karakter populasi sebagaimana sebuah penelitian sensus selama kaidah pengambilan sampelnya memenuhi kaidah ilmiah. Terkait dengan jumlah sampel diukur dari derajad keterwakilan anggota sampel (responden) yang dapat mewakili karakter populasi kawasan peremajaan dan penataan kawasan Tegalpanggung. Menurut (Yunus, 2010) disebutkan bahwa " besarnya sampel mengacu pada batasan jumlah 30 anggota sampel dimana untuk jumlah dibawah 30 disebut sebagai sampel kecil dan diatas 30 
sampel dianggap sebagai sampel besar. Hal serupa dikemukakan oleh Leedy (1980) mengatakan bahwa " the sampling distribution of means is very nearly normal for $N>30$ even when the population may be non normal".dalam penelitian ini, jumlah sampel populasi ditentukan sebesar 40 sampel (responden).

Pada penelitian ini jenis teknik sampling yang digunakan adalah dengan cara pengambilan sampel secara acak (random sampling). Dalam hal ini tipe sampling yang dipakai adalah tipe sampling purposive (purposive sampling/ judgemental sampling). Metode penelitian yang digunakan dalam melakukan evaluasi adalah metode diskriptif dengan menggunakan analisis kualitatif dan kualitatif. Penelitian ini akan menggambarkan dan menjelaskan tentang proses maupun hasil dari program peremajaan dan penataan kawasanpermukiman Tegalpanggung Kota Yogyakarta berdasarkan fakta-fakta sebagaimana adanya, dan mencoba untuk menilai keberhasilan program berdasarkan data yang diperoleh.

Secara Geografis Kota Yogyakarta terletak pada $110^{\circ} 24^{\prime} 19^{\prime \prime}-110^{\circ} 28^{\prime} 53^{\prime \prime}$ BT dan $07^{\circ} 15^{\prime} 24^{\prime \prime}-07^{\circ} 49^{\prime} 26^{\prime \prime}$ LS. Luas wilayah kota Yogyakarta adalah 3.250 Ha. Secara administrasi, Kota Yogyakarta terdiri dari 14 kecamatan, 45 kelurahan, 614 RW dan 2.524 RT. Kota Yogyakarta juga terletak di daerah dataran lereng aliran Gunung Merapi memiliki kemiringan lahan yang relatif datar (antara 0-2\%) dan berada pada ketinggian rata-rata 114 meter dari permukaan air laut (dpa). Sebagian wilayah dengan luas $1.657 \mathrm{Ha}$ terletak pada ketinggian kurang dari 100 meter dan sisanya $1.593 \mathrm{Ha}$ berada pada ketinggian antara 100-119 meter dpa.

Kelurahan Tegalpanggung merupakan bagian dari Kecamatan Danurejan dan merupakan salah satu kelurahan yang cukup padat penduduknya. Secara administratif Kelurahan Tegalpanggung terbagi menjadi 16 RW dan 66 RT. Terbagi dalam 5 perkampungan, antara lain Ledok Tukangna, Tukangan, Tegal Kemuning, Tegalpanggung dan Juminahan. Kampung Ledok Tukangan terdiri dari RW 1 sampai dengan RW 3. Kampung Tukangan terdiri dari RW 4 sampai dengan RW7, Kampung Tegal Kemuning terdiri dari RW 8 sampai dengan RW 10, Kmapung Tegalpanggung terdiri dari RW 11 sampai dengan RW 13, sedangkan kampung Juminahan terdiri dari RW 14 sampai dengan RW 16.

Kelurahan Tegalpanggung memiliki luas wilayah $0,35 \mathrm{~km}^{2}$ terletak di dataran rendah dengan ketinggian $113 \mathrm{~m}$ di atas permukaan laut. Kelurahan Tegalpanggung berbatasan langsung dengan sungai Code yang menjadikannya rawan terkena bencana banjir.
Topografi daerah penelitian terletak pada dataran rendah di sebelah selatan Gunung Merapi, ketinggian tempat 113 meter dpal. Lerengnya landai miring ke arah selatan sehingga aliran air permukaan dan air tanah sesuai dengan kemiringan lerengnya. Kondisi fisiografis ini sangat berpengaruh terhadap ketersediaan dan potensi sumberdaya alam. Karakteristik fisik lahan bervariasi sesuai dengan posisi, letak dan keanekaragaman fisiografinya.

Daerah penelitian dialiri oleh sungai Code yang bermata air di lereng Gunung Merapi. Debit air sungai ini sangat ditentukan oleh hujan di daerah lereng Merapi. Sungai tersebut merupakan sungai permanen dengan variasi debit sesuai dengan distribusi curah hujan menurut waktu pada seluruh daerah aliran sungai, namun kondisi daerah hulu menentukan variasi debit sungai.

Kelurahan tegalpanggung didominasi oleh penggunaan lahan sebagai perumahan penduduk dan sektor komersial. Perumahan juga membentang di sepanjang bantaran sungai Code. Daerah tersebut merupakan daerah padat penduduk. Layer pertama di sepnajang jalan-jalan utama seperti jalan Mas Suharto, Jalan Tukangan, Jalan Juminahan, Jalan Hayam Wuruk merupakan bangunan-bangunan relatif baru dengan kondisi yang masih bagus. Layer pertama di dominasi oleh kegiatan komersial seperti toko-toko kebutuhan sehari-hari. Ada pula sekolah, perkanotran, perhotelan, jasa-jasa dan perumahan. Sedangkan layer-layer berikutnya lebih di dominasi oleh rumah penduduk dengan kepadatan bangunan yang sangat tinggi. Kelurahan Tegalpanggung merupakan kelurahan yang terkatogori padat penduduk. Meskipun demikian kepadatan penduduk di Kelurahan Tegalpanggung pada tahun 2012-2013 mengalami penurunan 1900 jiwa $/ \mathrm{km}^{2}$. Jumlah penduduk pada tahun 2013 berjumlah 9100 jiwa dengan rincian 4511 laki-laki dan 4589 perempuan.

Pelaksanaan kegiatan ini dimaksudkan untuk menata kembali Kawasan Tegalpanggung agar menjadi kawasan yang lebih baik dan berkembang dengan potensi yang dimiliki, sedangkan tujuan pelaksanaan kegiatan ini adalah:

(1) Tersusunnya konsep penanganan kawasan perkotaan (urban renewal) yang meliputi skenario pengembangan kawasan atas beberapa bagian kawasan. Pada tahun pertama akan disusun detail desain perencanaan untuk bagian kawasan yang diprioritaskan untuk ditindak lanjuti dengan kegiatan penanganan fisik.

(2) Tersusunnya program investasi dan arahan pengendalian pelaksanaan penanganan kawasan perkotaan yang akan disepakati bersama 
pemerintah daerah dan masyarakat pada kawasan perencanaan.

Permukiman di bantaran kali Code Kelurahan Tegalpanggung mulai tumbuh sekitar tahun 1980-an dan berkembang secara organis dari tahun ke tahun nya. Permukiman di sekitar kali Code yang merupakan bagian dari Kelurahan Tegalpanggung tersebut tidak memiliki hak milik, Tanah permukiman Kampung Code merupakan tanah milik Keraton Yogyakarta berdasarkan sejarah pertanahan Kota Yogyakarta dan Peraturan perundangan yang berlaku special di Provinsi DIY. Sejarah pertanahan Kota Yogyakarta dalam perjanjian Giyanti tahun 1755 menunjukkan bahwa Keraton Yogyakarta menguasai tanah di kerajaannya yang didirikan di hutan Paberingan (terletak antara sungai Winongo dan Sungai Code). Selanjutnya dalam UU Nomor 13 Tahun 2012 tentang Keistimewaan DIY pada bab X tentang Pertanahan pada Pasal 32 Ayat 2 dalam UU disebutkan bahwa Kasultanan sebagai badan hukum merupakan subyek hak yang mempunyai hak milik atas tanah kasultanan. UU keistimewaan DIY tersebut adalah UU yang berlaku untuk masalah ini, sedangkan UU Pokok Agraria dan UU SDA tidak berlaku karena pada kasus ini berlaku asas lex specialis derogate legi generali yaitu asas penafsiran hukum yang bersifat khusus mengesampingkan hukum yang bersifat umum. Dengan adanya hal tersebut tanah bantaran sungai di sungai Code adalah milik kraton, tetapi semenjak kemerdekaan tanah tersebut di berikan kepada Pemerintah Daerah.

Secara umum kondisi di permukiman yang mendapatkan bantuan program peremajaan dan penataan ini dapat dikatakan sebagai permukiman kumuh yang menempati tanah illegal (squater area). Lokasi permukiman yang diremajakan di titik beratkan pada RW 1, RW 2, dan RW 3 Kelurahan Tegalpanggung. Letak RW tersebut berada di sekitar tanggul dan permukiman mereka hanya berjarak kurang lebih 5 meter dari bibir sungai. Berikut adalah ilustrasi kondisi permukiman yang diremajakan dan ditata pada kawasan kelurahan Tegalpanggung.

Kondisi Prasarana Lingkungan Permukiman Kumuh Sebelum Peremajaan

1. Open space/ ruang terbuka

Keberadaan ruang terbuka di Kawasan Tegalpanggung sangatlah terbatas. Dilihat dari foto udara terlihat bahwa kawasan ini didominasi oleh bangunan. Ruang terbuka yang ada pada umumnya berupa jalan (gang) dan sungai.

2. Jaringan Jalan

Di Kawasan Tegalpanggung, terdapat beberapa jenis jalan, yang dapat diklasifikasikan sebagai jalan raya perkotaan, jalan kampung, dan jalan rek kereta api. Jalan kampung atau jalan lingkungan di Kawasan Tegalpanggung, berdasar lebarnya dapat diklasifikasikan sebagai berikut :

(a) Lebar lebih dari 5 meter, yaitu jalan-jalan yang pendek (tak lebih dari 70m), merupakan cabang dari Jl. Tegalpanggung, yaitu gang Bougenvile, Kamboja, Mawar, dan Anyelir (RW 14 dan RW 15)

(b) Lebar antara 3-4 meter, yaitu gang Tegalpanggung II, jalan ini masih dapat dilalui mobil roda 4 tipe kecil.

(c) Lebar kurang dari 2 meter, atau jalan setapak, merupakan sebagian besar jalan di perkampungan Tegalpanggung.

3. Jaringan Drainase

Jaringan Drainase yang ada di Kawasan Tegalpanggung, pola jaringannya membentuk jaringjaring dan paralel dengan memanfaatkan Sungai Code sebagai outlet-nya. Saluran drainase ada yang mengikuti pola jalan dan ada juga yang memotong jalan dan bangunan untuk langsung di alirkan ke outlet-nya. Tetapi untuk ruas-ruas yang berdekatan langsung dengan Sungai Code pola jaringan drainasenya berbentuk siku dan memotong jalan menuju outlet-nya. Saluran drainase yang berada pada gang atau jalan kecil umumnya merupakan saluran tertutup, sedangkan untuk saluran yang berada di jalan yang sudah di aspal umumnya adalah saluran terbuka. Jenis inlet saluran drainase yang digunakan di kawasan perencanaan adalah Gutter inlet dengan memanfaatkan badan jalan secara plan atau horizontal inlet.

4. Sanitasi dan MCK

Sistem sanitasi yang ada di kawasan perencanaan adalah sistem sanitasi on-site treatment yaitu dengan menggunakan septic tank terutama untuk air buangan domestik. Telah tersedianya MCK (Mandi Cuci dan Kakus) di kawasan perencanaan di sepanjang Sungai Code sebanyak 8 unit yang merupakan bantuan baik dari Pemerintah dan KKN (Kuliah Kerja Nyata) mahasiswa cukup membantu dalam terciptanya lingkungan yang sehat.

Kondisi Prasarana Lingkungan Permukiman Kumuh Setelah Program Peremajaan

1. Open space/ruang terbuka

Ruang terbuka hijau yang disediakan di permukiman Tegalpanggung adalah berupa pot-pot tanaman yang sekaligus berfungsi sebagai kanopi (roof garden),namun pemanfaatannya tidak difungsikan secara optimal, karena tanaman yang ada tidak dipelihara dengan baik. Lapangan olahraga yang berfungsi sebagai ruang publik dan interaksi antar penghuni, pada awal konsep pembangunan akan 
menggunakan ruang terbuka namun hingga saat ini ruang tersebut tidak terelisasi sehingga pemanfaatannya tidak jelas. Padahal ruang publik tersebut sangat dibutuhkan oleh masyarakat untuk melakukan interaksi dan tukar informasi pada forumforum informal. Berdasarkan hasil interview di lapangan bahwa program penghijauan di lokasi Tegalpanggung bukan berasal dari Program Peremajaan kawasan melalui Dinas PUP-ESDM melainkan berasal dari program penghijauan BLH Kota Yogyakarta yang dilakukan secara bertahap.

2. Jaringan Jalan

Kondisi jalan akses hampir seluruh nya menggunakan perkerasan baik paving blok maupun beton cor dengan lebar antara 1-2 meter dan sebagian besar berhimpit langsung dengan tembok permukiman penduduk. Selain itu kondisi lahan yang menurun ke arah Sungai Code, membentuk pola sirkulasi dan bangunan mengikuti ketinggian kontur.

Dari hasil kuesioner didapat informasi bahwa lebar jalan kampung di Kelurahan Tegalpanggung sangat bervariasi diantaranya lebar jalan $0,5 \mathrm{~m}, 1 \mathrm{~m}, 1,5 \mathrm{~m}, 2$ $\mathrm{m}, 2,5 \mathrm{~m}$ dan $3 \mathrm{~m}$. Dengan keterbatasan lahan tersebut sehingga beberapa warga yang memiliki rumah dengan akses jalan sempit namun mempunyai kendaraan roda 2 atau bahkan roda 4 mereka memarkirkan kendaraan di lokasi yang memiliki space luas atau jalan dengan lebar mencukupi.

3. Jaringan SPAH dan Drainase

Saluran pembuangan air hujan (SPAH) di Kelurahan Tegalpanggung telah dilengkapi dengan jaringan saluran pembuangan. Bangunan SPAH tertutup diteruskan ke pembuangan/drainase akhir di Sungai Code. Permasalahan muncul ketika SPAH digunakan juga sebagai saluran pembuangan air limbah manusia, sehingga dua fungsi yang seharusnya dipisahkan menjadi bercampur. Akibatnya fungsi drainase menjadi tidak lancar karena limbah yang masuk ke dalam SPAH mengakibatkan pemampatan dan pendangkalan saluran. Tentunya hal ini akan mengurangi daya tampung air di SPAH untuk mengalirkan air hujan. Dampak yang terjadi adalah adanya luapan di sisi-sisi bangunan dan terjadi aliran air terbuka di permukaan tanah hingga masuk pada bangunan-bangunan publik yang lokasi lantainya lebih rendah. Kondisi SPAH setelah adanya program peremajaan sudah banyak yang mengalami kerusakan, dan banyak juga SPAH yang tertutup.

4. Sanitasi dan MCK

Di Kawasan kasus studi terdapat fasilitas sanitasi komunal untuk keperluan buang air besar untuk pemakaian bersama. Fasilitas sanitasi komunal dilayani dengan menggunakan MCK (Mandi, Cuci, Kakus).
Dalam hal ini, masyarakat tidak dilibatkan secara aktif dalam desain dan pelaksanaan fasilitas tersebut dan akibatnya tingkat rasa tanggung jawabnya masyarakat terhadap fasilitas tersebut menjadi rendah.

\section{Kriteria Kondisi Prasarana Lingkungan}

Penilaian terhadap perumahan dan permukiman dari aspek prasarana dan sarana lingkungan mencakup 5 kriteria, yaitu: tingkat pelayanan air bersih, sanitasi lingkungan, persampahan, air hujan dan kondisi jalan. Berdasarkan Kriteria Penetapan Kawasan Kumuh oleh Departemen PU (2007) kawasan Tegalpanggung memiliki kondisi sebagai berikut :

1. Kondisi jalan

Kondisi jalan kawasan kumuh di wilayah Tegalpanggung bervariasi. Terdapat jalan dengan kondisi yang baik terutama jalan yang telah mendapat bantuan baik dari pemerintah maupun pihak swasta. Jalan tersebut biasanya berupa perkerasan aspal maupun paving block. Namun ada berapa jalan yang kondisinya sangat buruk karena belum mendapat bantuan. Kondisi jalan tersebut biasa perkerasan semen (cor block) dan perkerasan tanah. Terdapat 63\% jalan lingkungan dan jalan setapak yang memiliki kondisi yang baik dan hanya $37 \%$ lahan yang memiliki kondisi buruk, dengan pola letak jalan dan permukiman yang belum tertata dengan baik.

2. Kondisi Drainase

Umumnya kualitas drainase lingkungan di Kelurahan Tegalpanggung merupakan saluran yang permanen, namun kondisinya rusak dan tersumbat sampah (72\%), sehingga saluran air hujan tidak dapat berfungsi dengan baik. Pada musim hujan kondisi ini mempercepat naiknya permukaan air yang dapat menyebabkan banjir. Hanya 28\% kondisi saluran air hujan yang tidak permanen (berupa galian), namun kurang efektif mengalirkan air karena kemiringan drainase dipengaruhi oleh kontur tanah.

3. Kondisi Air Bersih

Di RW 1, 2, 3 Kelurahan Tegalpanggung sebagian besar penduduk telah memperoleh air bersih dari saluran PAM 85\% dan 15\% masyarakat masih memanfaatkan air sumur (air tanah) untuk di konsumsi. Pada lokasi tertentu masih dapat diperoleh air dari sumur galian, namun kualitas air kurang baik akibat resapan air dari sungai, sehingga hanya dapat dipergunakan untuk fungsi MCK. Berdasarkan kondisi ini kurang lebih terdapat $15 \%$ dari penduduk yang tidak terlayani air bersih, sehingga dapat dikategorikan sebagai kumuh ringan.

4. Kondisi Air Limbah

Kondisi air limbah ini terkait dengan kondisi dan keberadaan drainase yang dimiliki kawasan kumuh. Untuk daerah yang memiliki drainase buangan limbah 
dibuang ke drainase yang berupa riol-riol sedangkan untuk daerah yang tidak memiliki drainase air buangan langsung dibuang ke tanah atau sungai. Dari kondisi sanitasi lingkungan sebagian besar penduduk belum menyadari pentingnya kesehatan lingkungan. Hal ini nampak pada kebiasaan penduduk yang membuang air kotor rumah tangga ke sungai (80\%) dan hanya $20 \%$ rumah yang memiliki saluran ke riol kota. Sedangkan jika ditinjau dari cara jamban penduduk, 60\% penduduk jamban di WC umum bahkan ada yang di sungai dan hanya $40 \%$ yang telah memiliki WC/KM di rumah. Dengan demikian berdasarkan kondisi tersebut dikategorikan sebagai kumuh sedang.

\section{Kondisi Persampahan}

Umumnya penduduk di Kelurahan Tegalpanggung membuang sampah di sungai (35\%), (50\%) sudah menggunakan jasa pengangkutan sampah dan selebihnya membakar sampah (15\%) di pekarangan atau di tempat-tempat terbuka. Lokasi akses jalan yang tidak mencukupi menyebabkan armada angkutan sampah serta gerobak sampah tidak dapat melayani secara maksimal menyebabkan penduduk lebih memilih cara yang mudah dilakukan dan tempat yang mudah dijangkau. Dari cara membuang sampah penduduk, kondisi ini dapat dikategorikan sebagai kumuh sedang.

Dari kondisi yang ada di lapangan didapatkan karakteristik permukiman kumuh di Kelurahan Tegalpanggung Kota Yogyakarta: (1) sarana \& prasarana air bersih belum terdistribusi merata, pembuangan air kotor dan pembuangan sampah yang tidak memenuhi persyaratan kesehatan; (2) kualitas lingkungan yang rendah (3) kualitas bangunan yang rendah (4) tingkat pertambahan penduduk yang tinggi (5) tingkat kemiskinan yang tinggi.

Sosialisasi kegiatan pemerintah khususnya mengenai peremajaan dan penataan prasarana lingkungan di kawasan Tegalpanggung harus lebih ditingkatkan. Berdasarkan data dari penduduk sebanyak $64 \%$ menyatakan di tempat mereka tidak pernah dilakukan sosialisasi, hanya $36 \%$ yang menyatakan pernah dilakuakan sosialisasi/ pemberitahuan mengenai program peremajaan dan penataan prasarana lingkungan di kawasan Tegalpanggung.
Kesadaran penduduk dalam mengikuti sosialisasi cenderung masih rendah, terlihat dari banyaknya penduduk yang tidak mengikuti jika ada sosialisasi yaitu sebanyak 57,5\%, kadang-kadang mengikuti $20 \%$ dan hanya $22,5 \%$ yang selalu mengikuti jika ada sosialisasi.

Penduduk yang pernah terlibat dalam penyusunan DED Rencana program peremajaan dan penataan prasarana lingkungan di kawasan Tegalpanggung sebanyak $27,5 \%$ sedangkan sebanyak $72,5 \%$ tidak pernah terlibat. Hal ini menunjukkan bahwa keterlibatan penduduk dalam penyusunan dan pemberian masukan terhadap Rencana program peremajaan dan penataan prasarana lingkungan di kawasan Tegalpanggung masih rendah.

\section{Kecukupan Masyarakat Terhadap program}

Analisis tingkat kecukupan capaian program dalam pelaksanaan program peremajaan kawasan diukur dengan menggunakan indikator berdasarkan komponen keberhasilan fisik. Kecukupan capaian program dalam pelaksanaan program peremajaan kawasan, terlebih dahulu dilakukan analisis keberhasilan fisik lingkungan permukiman. Dari hasil analisa dan pembahasan terhadap kondisi fisik lingkungan dapat dilakukan sintesa dampak program disajikan pada Tabel 1 .

Berdasarkan Tabel 1 tentang Analisis Keberhasilan Fisik, dan Sosial Pelaksanaan Program di atas diketahuni bahwa hasil yang didapatkan pada tiap-tiap lokasi berbeda-beda, karena tidak setiap lokasi mengalami peningkatan di setiap aspek fisik/ lingkungan. Selain analisis di atas, dilakukan juga analisis menggunakan hasil penyebaran kuisioner kepada penerima bantuan, untuk mengetahui tingkat keberhasilannya.

Berdasarkan pada Tabel 2 hasil analisis penilaian terhadap kondisi ketersediaan air bersih diatas didapatkan bahwa tanggapan dari responden terkait dengan adanya air bersih relative tidak banyak mengalami perubahan. Adanya fasilitas MCK umum dinilai sangat bermanfaat oleh masyarakat, koresponden menyatakan bahwa kondisi MCK saat ini berubah menjadi lebih baik (Tabel 3). 
Tabel 1. Sintesa Penilaian Dampak Program terhadap Kondisi Fisik Lingkungan di Kelurahan Tegalpanggung.

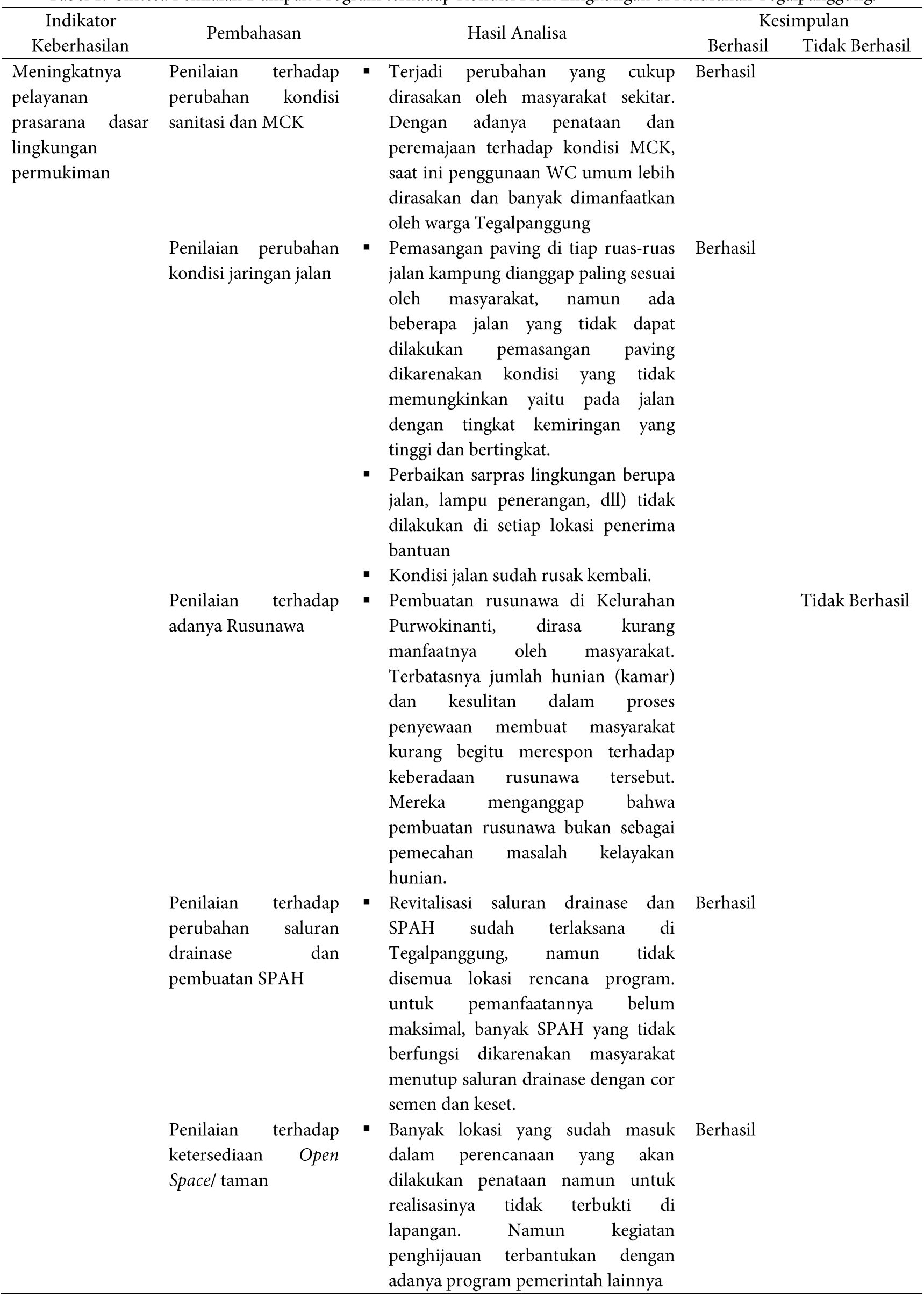


Lanjutan Tabel 1.

\begin{tabular}{llll}
\multicolumn{1}{c}{$\begin{array}{c}\text { Indikator } \\
\text { Keberhasilan }\end{array}$} & \multicolumn{2}{c}{ Pembahasan } & \multicolumn{2}{c}{ Hasil Analisa } & Kesimpulan \\
Berhasil & Tidak Berhasil \\
\hline $\begin{array}{l}\text { Meningkatnya } \\
\text { pelayanan }\end{array}$ & Penilaian terhadap & yang diusung dari dinas BLH Kota & Berhasil \\
prasarana dasar & Spacel taman & Ypen & Yogyakarta. \\
lingkungan & & Kegiatan tersebut memberikan & \\
permukiman & & dampak yang positif kepada & \\
\hline
\end{tabular}

Sumber : Hasil Analisis, 2014

Tabel 2. Penilaian Responden terhadap Ketersediaan Air Sebelum dan Sesudah Adanya Program Peremajaan dan Penataan Kawasan.

\begin{tabular}{|c|c|c|c|c|c|}
\hline \multirow{2}{*}{ No. } & \multirow{2}{*}{ Ketersediaan Air Bersih } & \multicolumn{2}{|c|}{ Sebelum Program Penataan } & \multicolumn{2}{|c|}{ Setelah Program Penataan } \\
\hline & & Jumlah & Persentase & Jumlah & Persentase \\
\hline 1 & Sangat tersedia & 0 & 0 & 0 & 0 \\
\hline 2 & Tersedia & 20 & 50 & 25 & 62.5 \\
\hline 3 & Cukup & 15 & 37.5 & 12 & 30 \\
\hline 4 & Kurang Tersedia & 5 & 12.5 & 3 & 7.5 \\
\hline \multirow[t]{2}{*}{5} & Tidak tersedia & 0 & 0 & 0 & 0 \\
\hline & Jumlah & 40 & 100 & 40 & 100 \\
\hline
\end{tabular}

Tabel 3. Penilaian Responden terhadap Kondisi Sanitasi dan MCK Sebelum dan Sesudah Adanya Program Peremajaan dan Penataan Kawasan.

\begin{tabular}{clcccc}
\hline \multirow{2}{*}{ No. } & \multirow{2}{*}{ Kondisi Sanitasi dan MCK } & \multicolumn{2}{c}{ Sebelum Program Penataan } & \multicolumn{2}{c}{ Setelah Program Penataan } \\
& Jumlah & 0 & Persentase & Jumlah & 0 \\
Persentase \\
\hline 1 & Sangat baik & 0 & 0 & 2 & 5 \\
2 & Baik & 23 & 58 & 26 & 65 \\
3 & Cukup baik & 17 & 42 & 12 & 30 \\
4 & Buruk & 0 & 0 & 0 & 0 \\
5 & Sangat buruk & 40 & 100 & 40 & 100 \\
\hline
\end{tabular}

Hasil analisis Tabel 4 menunjukkan bahwa jumlah sampel yang mengalami perubahan ada sebanyak 30 responden mengalami peningkatan, sedangkan 10 responden tidak mengalami perubahan/tetap. Artinya bahwa ada peningkatan terhadap kondisi jalan setelah adanya program penataan dan peremajaan prasarana lingkungan di kawasan Tegalpanggung.

Berdasarkan hasil analisis Tabel 5, penilaian terhadap kondisi ketersediaan SPAH dan saluran drainase diatas didapatkan bahwa tanggapan dari responden terkait dengan adanya SPAH dan saluran drainase relatif tidak banyak mengalami perubahan. Berdasarkan hasil analisis Tabel 6, penilaian terhadap ketersediaan Open Space dan Taman setelah adanya program penataan dan peremajaan prasarana lingkungan 60\% menyatakan kondisi ketersediaan Open Space dan Taman cukup baik.

\section{Responsifitas / Kepuasan Masyarakat Terhadap Program}

Analisis responsifitas dilakukan untuk mengetahui bagaimana kepuasan terhadap program peremajaan di
Kelurahan Tegalpanggung. Analisis ini dilakukan untuk mengetahui persepsi/respon masyarakat. Data yang diperoleh merupakan data hasil kuesioner dari masyarakat penerima program peremajaan di Tegalpanggung dengan menanyakan persepsi (kepuasan) mereka terhadap program yang dilakukan pemerintah Kota Yogyakarta. Hasil data kemudian diolah dan diinterpretasikan secara diskriptif kualitatif untuk diketahui bagaimana kepuasan masyarakat terhadap program peremajaan di Tegalpanggung.

Penilaian ini dilakukan untuk mengetahui respon atau tingkat kepuasan masyarakat, berikut adalah penilaian masyarakat terhadap hasil peremajaan yang di lakukan di Kelurahan Tegalpanggung (Tabel 7). Dengan demikian maka dapat disimpulkan bahwa kepuasan masyarakat terhadap hasil program peremajaan dan penataan prasarana lingkungan kawasan permukiman Tegalpanggung adalah sebagai berikut. 


\section{$\frac{\text { jumlah penilaian }}{\text { jumlah komponen penilaian keberhasilan }} \times 100 \%$}

Dari hasil perhitungan tersebut maka kepuasan masyarakat terhadap hasil pelaksanaan program peremajaan dan penataan prasarana lingkungan kawasan permukiman Tegalpanggung adalah sebesar
$56 \%$ yang berarti masyarakat menyatakan cukup puas. Hasil dari program ini memberikan manfaat bagi masyarakat yaitu mereka merasa dengan adanya program tersebut prasarana lingkungan kawasan Tegalpanggung dapat terpenuhi dengan cukup baik.

Tabel 4. Penilaian Responden terhadap Kondisi Prasarana Jaringan Jalan Sebelum dan Sesudah Adanya Program Peremajaan dan Penataan Kawasan.

\begin{tabular}{clcccc}
\hline \multirow{2}{*}{ No. } & \multirow{2}{*}{ Kondisi Prasarana Jaringan Jalan } & \multicolumn{2}{c}{ Sebelum Program Penataan } & \multicolumn{2}{c}{ Setelah Program Penataan } \\
& & Jumlah & Persentase & Jumlah & Persentase \\
\hline 1 & Sangat baik & 0 & 0 & 0 & 0 \\
2 & Baik & 8 & 20 & 23 & 57.5 \\
3 & Cukup baik & 22 & 55 & 9 & 22.5 \\
4 & Buruk & 10 & 25 & 8 & 20 \\
5 & Sangat buruk & 0 & 0 & 0 & 0 \\
& $\quad$ Jumlah & 40 & 100 & 40 & 100 \\
\hline
\end{tabular}

Tabel 5. Penilaian Responden terhadap Kondisi SPAH dan Drainase Sebelum dan Sesudah Adanya Program Peremajaan dan Penataan Kawasan.

\begin{tabular}{clcrrr}
\hline \multirow{2}{*}{ No. } & \multicolumn{2}{c}{ Kondisi SPAH Dan Drainase } & \multicolumn{2}{c}{ Sebelum Program Penataan } & \multicolumn{2}{c}{ Setelah Program Penataan } \\
& & Jumlah & Persentase & Jumlah & Persentase \\
\hline 1 & Sangat baik & 0 & 0 & 0 & 0 \\
2 & Baik & 1 & 2.5 & 3 & 7.5 \\
3 & Cukup baik & 15 & 37.5 & 22 & 55 \\
4 & Buruk & 18 & 45 & 14 & 35 \\
5 & Sangat buruk & 6 & 15 & 1 & 2.5 \\
& & 40 & 100 & 40 & 100 \\
\hline
\end{tabular}

Tabel 6. Penilaian Responden terhadap Ketersediaan Open Space Sebelum dan Sesudah Adanya Program Peremajaan dan Penataan Kawasan.

\begin{tabular}{|c|c|c|c|c|c|}
\hline \multirow{2}{*}{ No. } & \multirow{2}{*}{ Ketersediaan Open Space Dan Taman } & \multicolumn{2}{|c|}{ Sebelum Program Penataan } & \multicolumn{2}{|c|}{ Setelah Program Penataan } \\
\hline & & Jumlah & Persentase & Jumlah & Persentase \\
\hline 1 & Sangat baik & 0 & 0 & 0 & 0 \\
\hline 2 & Baik & 1 & 2.5 & 2 & 5 \\
\hline 3 & Cukup baik & 17 & 42.5 & 24 & 60 \\
\hline 4 & Buruk & 20 & 50 & 13 & 32.5 \\
\hline 5 & Sangat buruk & 2 & 5 & 1 & 2.5 \\
\hline & Jumlah & 40 & 100 & 40 & 100 \\
\hline
\end{tabular}

Tabel 7. Tingkat Responsifitas Pelaksanaan Program Menurut Masyarakat

\begin{tabular}{lcccccc}
\hline \multicolumn{1}{c}{ Program } & $\begin{array}{c}\text { Sangat } \\
\text { puas }\end{array}$ & Puas & $\begin{array}{c}\text { Cukup } \\
\text { puas }\end{array}$ & $\begin{array}{c}\text { Kurang } \\
\text { puas }\end{array}$ & $\begin{array}{c}\text { Tidak } \\
\text { puas }\end{array}$ & Total \\
\hline Pembuatan Rumah Susun Graha Bina & $0 \%$ & $20 \%$ & $27.5 \%$ & $45 \%$ & $7.5 \%$ & $100 \%$ \\
Harapan & & & & & & \\
Saluran Drainase dan SPAH & $0 \%$ & $7.5 \%$ & $55 \%$ & $37.5 \%$ & $0 \%$ & $100 \%$ \\
Sanitasi & $0 \%$ & $7.5 \%$ & $60 \%$ & $32.5 \%$ & $0 \%$ & $100 \%$ \\
Ruang Terbuka Hijau & $0 \%$ & $5 \%$ & $62.5 \%$ & $30 \%$ & $2.5 \%$ & $100 \%$ \\
Pelebaran Jalan Lingkungan & $0 \%$ & $7.5 \%$ & $52.5 \%$ & $32.5 \%$ & $7.5 \%$ & $100 \%$ \\
\hline
\end{tabular}

Sumber : Hasil Analisa Kuesioner, 2014 


\section{KESIMPULAN}

Kesimpulan dari evaluasi pelaksanaan program Penataan dan peremajaan prasarana lingkungan di kawasan Kelurahan Tegalpanggung Kota Yogyakarta ini antara lain:

1. Program Penataan dan Peremajaan Prasarana Lingkungan di Kawasan Tegalpanggung Kota Yogyakarta dinilai cukup berhasil dalam mecapai tujuan program yang telah di tetapkan yaitu agar menjadi kawasan yang lebih baik dan berkembang dengan potensi yang dimiliki. Dengan demikian maka program Penataan dan Peremajaan Prasarana Lingkungan di Kawasan Tegalpanggung dinilai cukup efektif.

2. Dari aspek fisik, program Penataan dan Peremajaan Prasarana Lingkungan di Kawasan Tegalpanggung secara umum dapat memberikan perubahan yang positif dan dinilai berhasil dalam memperbaiki kondisi fisik prasarana lingkungan permukiman yang lebih baik dari kondisi lingkungan sebelumnya. Kondisi ini dapat terlihat dari hasil penelitian yaitu kondisi prasarana lingkungan permukiman seperti air bersih, drainase dan SPAH, open space dan taman, jaringan jalan mengalami peningkatan yang cukup signifikan setelah adanya penataan dan peremajaan.

3. Program Penataan dan Peremajaan Prasarana Lingkungan di Kawasan Tegalpanggung mendapat respon kepuasan dari masyarakat setempat karena adanya manfaat bagi mereka. Secara keseluruhan masyarakat merespon cukup puas terhadap pelaksanaan Program Penataan dan Peremajaan Prasarana Lingkungan di Kawasan Tegalpanggung. Respon masyarakat terhadap Program Penataan dan Peremajaan Prasarana Lingkungan adalah sebagai berikut :

(a) Pembuatan rusunawa masyarakat merasa kurang puas dengan prosentase $45 \%$. Persepsi ini timbul karena masyarakat menganggap bahwa pembuatan rusunawa tidak sepenuhnya dapat dirasakan oleh masyarakat Tegalpanggung.

(b) Peremajaan terhadap saluran drainase dan SPAH respon masyarakat cukup puas. Adanya saluran drainase dan pembuatan SPAH lokasi mereka jarang yang terkena genangan air pada saat hujan. 55\% masyarakat merasa cukup puas, dan $37.5 \%$ masyarakat merasa kurang puas.

(c) Pembuatan saluran sanitasi dan penataan WC umum masyarakat merespon cukup puas, karena saat ini WC umum sudah dapat dimanfaatkan oleh masyarakat dan makin bertambah yang menggunakannya.

(d) Ruang terbuka hijau (open space) sebanyak $62,5 \%$ masyarakat merasa cukup puas dengan adanya program penghijauan. Namun pada kenyataannya dilapangan program penataan Open Space yang sudah direncanakan pada program tidak ada yang berjalan. Penghijauan dengan tamanisasi dan potisasi didapat dari program BLH Kota Yogyakarta secara bertahap.

(e) Pelebaran jalan dan pavingisasi di ruas-ruas jalan kampung permukiman Tegalpanggung mendapat respon yang cukup, masyarakat cukup puas dengan adanya program tersebut. Dari hasil kuesioner di dapat $52.5 \%$ respon menyatakan cukup puas, dan $32.5 \%$ masyarakat merasa kurang puas.

4. Responsifitas Masyarakat

Kepuasan masyarakat terhadap pelaksanaan program Penataan dan Peremajaan Prasarana Lingkungan Permukiman Tegalpanggung adalah sebesar 56\% yang berarti masyarakat menyatakan cukup puas terhadap program ini berarti menunjukkan bahwa program penataan dan peremajaan prasarana lingkungan cukup berhasil dalam memberikan nilai kepuasan terhadap masyarakat.

5. Dari aspek sarana dan prasarana (menurut kriteria kawasan kumuh oleh Departemen PU, 2007) dapat disimpulkan sebagian besar kondisi prasarana lingkungan yang ada termasuk dalam kategori kumuh sedang. Kebiasaan penduduk membuang sampah, air kotor dan jamban di sungai, menjadikan sungai tercemar. Akibat kurangnya kesadaran penduduk terhadap kesehatan lingkungan, sehingga berimplikasi pada kualitas lingkungan yang rawan bencana banjir dan kualitas hidup penduduk yang rentan terhadap wabah penyakit. Salah satu penyebab tingginya tingkat kepadatan permukiman di Kelurahan Tegalpanggung adalah banyaknya penduduk pendatang yang datang dan bermukim karena alasan letak lokasi kerja dan keberadaan keluarga yang sudah tinggal di lokasi. Hal ini menyebabkan rumah tumbuh padat dan tidak teratur dan kondisi sarana-prasarana yang buruk. Kondisi sosial ekonomi penduduk yang umumnya berpenghasilan sangat rendah, menyebabkan rendahnya motivasi penduduk untuk memiliki rumah yang layak \& sehat. Kemudian implikasi dari tingginya tingkat kepadatan bangunan di lokasi menyebabkan kurangnya ruang terbuka. 


\section{DAFTAR PUSTAKA}

Dunn, N. Williams. (2000). Analisis Kebijakan Publik. Edisi kedua cetakan 4. Yogyakarta. Gadjah Mada Univresity Press.

Ridlo, M. Agung. (2001). Kemiskinan Di Perkotaan. Semarang. Unissula Press.

Sastra, Suparno dan Endy Marlina. (2006). Perencanaan dan Pengembangan Perumahan. Yogyakarta. Andi.

Sri Kurniasih. (2007). Usaha Perbaikan Permukiman Kumuh di Petukangan Utara - Jakarta Selatan. Jakarta. Teknik Arsitektur Universitas Budi Luhur.

Yudohusodo, S. (1991). Rumah Untuk Seluruh Rakyat, INKOPPOL. Jakarta. Unit Percetakan Bharakerta.
Yunus, Hadi Sabari. (1987). Subject Matter dan Metode Penelitian Geografi Permukiman Kota. Yogyakarta. Fakultas Geografi Universitas Gadjah Mada.

Yunus, Hadi Sabari. (1987). Geografi Permukiman dan Permasalahan Permukiman di Indonesia. Yogyakarta. Fakultas Geografi UGM.

Yunus, Hadi Sabari. (2008). Dinamika Wilayah PeriUrban Determinan Masa Depan Kota. Yogyakarta. Pustaka Pelajar,

Yunus, Hadi Sabari. (2008). Bahan Ajar Mata Kuliah Permukiman. Yogyakarta Program Studi Ilmu Lingkungan. Sekolah Pasca Sarjana. UGM,

Yunus, Hadi Sabari. (2010). Metodologi Penelitian Wilayah Kontemporer. Yogyakarta. Pustaka Pelajar. 